\title{
Effect of land configurations and Pongamia mulch on soil moisture content and yield of yellow pericarp sorghum during kharif
}

\author{
K. Jaisimha Reddy* \\ College of Agriculture, PJTSAU, Rajendranagar, Hyderabad (Telangana State), India \\ G. S. Madhubindu \\ Department of Agronomy, College of Agriculture, PJTSAU, Rajendranagar, Hyderabad \\ (Telangana State), India

\section{S. A. Hussain} \\ College Farm, College of Agriculture, PJTSAU, Rajendranagar, Hyderabad (Telangana State), \\ India \\ M. Uma Devi \\ Water Technology Centre, College of Agriculture, PJTSAU, Rajendranagar, Hyderabad, \\ (Telangana State), India \\ *Corresponding author. Email: kjaisimhareddy66@gmail.com
}

\section{Article Info}

https://doi.org/10.31018/

jans.v13i2.2705

Received: May 5, 2021

Revised: June 8, 2021

Accepted: June 10, 2021

\section{How to Cite}

Reddy, K.J. et al. (2021). Effect of land configurations and Pongamia mulch on soil moisture content and yield of yellow pericarp sorghum during kharif. Journal of Applied and Natural Science, 13(2), 786 - 790. https://doi.org/10.31018/jans.v13i2.2705

\begin{abstract}
The present work aims to determine the effect of land configurations and Pongamia pinnata mulch on soil moisture content and yield of yellow sorghum during kharif, 2018-19 on sandy clay loam soils of Hyderabad. The experiment was conducted at the College of Agriculture, Professor Jayashankar Telangana State Agricultural University, Rajendranagar, Hyderabad. The treatments included land configurations (Flatbed, Ridge and furrow, Broad bed and furrow, Flatbed + Mulch, Ridge and Furrow + Mulch, Broad bed and furrow + Mulch) and yellow sorghum genotypes (PYPS 101, PYPS 102, PYPS 103 and PYPS 104). Mulch used in this investigation was Pongamia leaf mulch applied @ $6 \mathrm{t} \mathrm{ha}^{-1}$ uniformly at 20 DAS. Soil moisture played a vital role in increasing crop yields in the rainfed regions of the semi-arid tropics. During most crop growth stages, the availability of soil water was increased by Broad bed and furrow + mulch, resulting in increased grain yield by $37 \%\left(1701 \mathrm{~kg}\right.$ ha $\left.{ }^{-1}\right)$ of yellow sorghum over flatbed. Ridge and furrow + mulch were found to be the next best treatment, with a grain yield of $1590 \mathrm{~kg} \mathrm{ha}^{-1}$. Mulched treatments of flatbed, ridge and furrow and broad bed and furrow increased the grain yield by $20 \%, 28 \%$ and $37 \%$, respectively, compared to flatbed without mulch. The present study will help in recognizing profitable moisture conservation practices and the role of Pongamia mulch in soil moisture conservation and yield maximization of yellow sorghum.
\end{abstract}

Keywords: Land configuration, Pongamia mulch, Soil moisture, Yellow pericarp sorghum, Sorghum genotypes

\section{INTRODUCTION}

Sorghum is one of the main staple food for the world's poorest people across the semi-arid tropics. It is one of the five major cereals in the country and contributes to about $16 \%$ of the world's sorghum production. The crop is being cultivated over an area of 5.65 million hectares with a production of 4.41 million tonnes and a productivity of $780 \mathrm{~kg} \mathrm{ha}^{-1}$ (Agricultural Statistics at a Glance, 2016). In Telangana, sorghum is cultivated in 80,000 ha with a production of 70,000 tonnes and productivity of $1051 \mathrm{~kg} \mathrm{ha}^{-1}$. Out of the total cultivated area under sorghum in Telangana, $60 \%$ of 48,000 ha is under rainfed conditions. However, the area under sorghum is declin- ing every year all across India (from 18 million ha in 1960 to 5.65 million ha in 2015-16). This decline in the area is mainly due to competing crops such as rice, wheat, maize, cotton, sugarcane, chilli, soybean and groundnut. Besides, low market prices of kharif sorghum due to grain mold. Hence, alternate use of sorghum is the need of the hour to improve socioeconomic conditions of the farmers.

One of the unique features of sorghum is its variation in grain colour. The colour of the grain can vary from red, lemon-yellow, white, to black. Yellow pericarp sorghums are generally raised in patches in tribal areas of Telangana during kharif for subsistence with minimum management practices resulting in low yields and sus- 
ceptibility to pests and diseases. However, due to the high nutritional, good roti-making and keeping qualities of yellow sorghum, it has created a demand for an increase in its area and production with improved cultures. Yellow sorghums are typically tall statured as against the white sorghum and are susceptible to lodging when raised under improved management practices during rabi and summer. Hence, they are invariably cultivated during kharif season in Telangana.

Moisture conservation under rainfed conditions can be accomplished by proper land management, which plays a major role in minimizing soil erosion and improving water use efficiency of field crops (Singh et al., 2015). Land configurations viz., ridge and furrow and bed systems have been known to be a more feasible and practicable proposition to conserve soil moisture and dispose of additional rainwater (runoff) in rainfed regions (Jinger et al., 2017). On the other hand, Mulch has a great role in soil moisture conservation by modifying microclimatic soil conditions. It helps to prevent weed growth, reduce evaporation, and increase rainwater infiltration during the growing season (Sarolia and Bhardwaj, 2012). Different types of organic mulches have been used to obtain good crop growth and yield in crops like groundnut, soybean, sesame, sunflower etc.

\section{MATERIALS AND METHODS}

A field experiment was conducted at the College of Agriculture, Professor Jayashankar Telangana State Agricultural University (PJTSAU), Rajendranagar, Hyderabad, during kharif, 2018-19 from $5^{\text {th }}$ July to $22^{\text {nd }}$ October. The perusal of the data revealed that the soil was sandy clay loam in texture, neutral in reaction (6.83), low $(0.46 \%)$ in organic carbon, low $\left(224 \mathrm{~kg} \mathrm{ha}^{-1}\right)$ in available nitrogen, medium $\left(37.2 \mathrm{~kg} \mathrm{ha}^{-1}\right)$ in available phosphorus and high $\left(467.6 \mathrm{~kg} \mathrm{ha}^{-1}\right)$ in available potassium. The bulk density of $0-15 \mathrm{~cm}$ and $15-30 \mathrm{~cm}$ was $1.48 \mathrm{~g} \mathrm{c}^{-1} \mathrm{c}^{-1}$ and $1.58 \mathrm{~g} \mathrm{c}^{-1} \mathrm{c}^{-1}$, respectively. The soil moisture content in $0-15 \mathrm{~cm}$ and $15-30 \mathrm{~cm}$ depth at field capacity was 19.2 and $17.8 \%$, respectively and at a permanent wilting point were 8.7 and $7.5 \%$, respectively. The total rainfall received during the growth period was $333.8 \mathrm{~mm}$ in 21 rainy days.

The experiment was laid out in strip plot design with six (6) land configurations as main plots and four (4) yellow pericarp genotypes in subplots. The main plot treatments included were $M_{1}$ - Flatbed, $M_{2}-$ Ridge and furrow, $M_{3}-$ Broad bed and furrow, $M_{4}-$ Flat bed + Mulch, $M_{5}-$ Ridge and Furrow + Mulch, $M_{6}-$ Broad bed and furrow + Mulch. Mulch applied is Pongamia leaf @ $6 \mathrm{t}$ $\mathrm{ha}^{-1}$. The subplots treatments were PYPS 101, PYPS 102, PYPS 103 and PYPS 104. The net plot area was $4.05 \times 4.2 \mathrm{~m}$. The spacing adopted for sowing was 45 $\mathrm{cm} \times 15 \mathrm{~cm}$. Green leaf of Pongamia, used as mulch @ $6 \mathrm{t} \mathrm{ha}^{-1}$ was spread between the crop rows in uniform thickness at 20 DAS. The crop was planted on 5.07.2018 and harvested on 22.10.2018. Broad beds and furrows were laid with a bed width of $135 \mathrm{~cm}$ and $15 \mathrm{~cm}$ deep furrow. Similarly, for ridges and furrows, a depth of $15 \mathrm{~cm}$ was maintained. Proper care was taken to maintain the same number of crop rows (12 rows) and total number of plants in each configuration. Urea, Diammonium phosphate and muriate of potash were used as sources at recommended dosages of 60:40:30 $\mathrm{kg} \mathrm{N}: \mathrm{P}_{2} \mathrm{O}_{5}: \mathrm{K}_{2} \mathrm{O}$ ha $^{-1}$. The recommended dose of nitrogen @ $60 \mathrm{~kg} \mathrm{ha}^{-1}$ was applied as a uniform dose in two splits, one as basal and the other at 30 DAS. The entire recommended phosphorus (40 kg ha $\left.{ }^{-1}\right)$ and potash (30 $\mathrm{kg} \mathrm{ha}^{-1}$ ) were applied as basal at the time of sowing uniformly to all the plots. Soil moisture was estimated from two soil depths viz., $0-15$ and $15-30 \mathrm{~cm}$ by gravimetric method.

\section{RESULTS AND DISCUSSION}

The data revealed that land configurations significantly $(P=0.05)$ influenced the soil moisture of yellow sorghum. But, the effect of genotypes was found to be non -significant. In comparison, the yield of yellow sorghum differed significantly due to land configurations and genotypes. The interaction effect was found to be nonsignificant $(P=0.05)$ in both cases.

\section{Soil moisture content}

As observed from Fig. 1a \& 1b, the soil moisture contents varied according to the rainfall that occurred during the crop growth period. Whereas the soil moisture contents varied according to the rainfall that occurred during the crop growth period. Weekly total rainfall of $\geq$ $5 \mathrm{~cm}$ occurred during $1^{\text {st }}, 3^{\text {rd }}$ and $5^{\text {th }}$ week after sowing. Correspondingly, the moisture contents observed during those weeks were maximum, ranging from 9.76 to $11.74 \%$ in $0-15 \mathrm{~cm}$ soil depth. The soil moisture content of $0-15 \mathrm{~cm}$ soil depth was found equivalent both in ridges and furrows with mulch $\left(\mathrm{M}_{5}\right)$ and broad beds and furrows $\left(M_{6}\right)$ with mulch whenever there is a rain event during any week. However, during the weeks when there is no rain, the soil moisture contents were highest under broad beds and furrows with mulch $\left(\mathrm{M}_{6}\right)$. Gnanasoundari and Balusamy (2015) at Coimbatore, Tamil Nadu and Ankita Negi et al. (2018) at Pantnagar, Uttarakhand recorded similar results for broad beds and furrows and ridges and furrows, respectively. However, during the weeks where there is no rain, the soil moisture contents were highest under broad beds and furrows with mulch (M6). Intermittent and welldistributed showers starting from sowing to soft dough stage were tapped well under broad beds and furrows with mulch (M6) and ridges and furrows with mulch (M5). But from there on, with the receding of rains, the soil moisture depleted gradually towards harvest. Dur- 
Table 1. Grain yield $\left(\mathrm{kg} \mathrm{ha}^{-1}\right)$ and Stover yield $\left(\mathrm{kg} \mathrm{ha}^{-1}\right)$ of yellow sorghum as influenced by land configuration, mulching and genotypes.

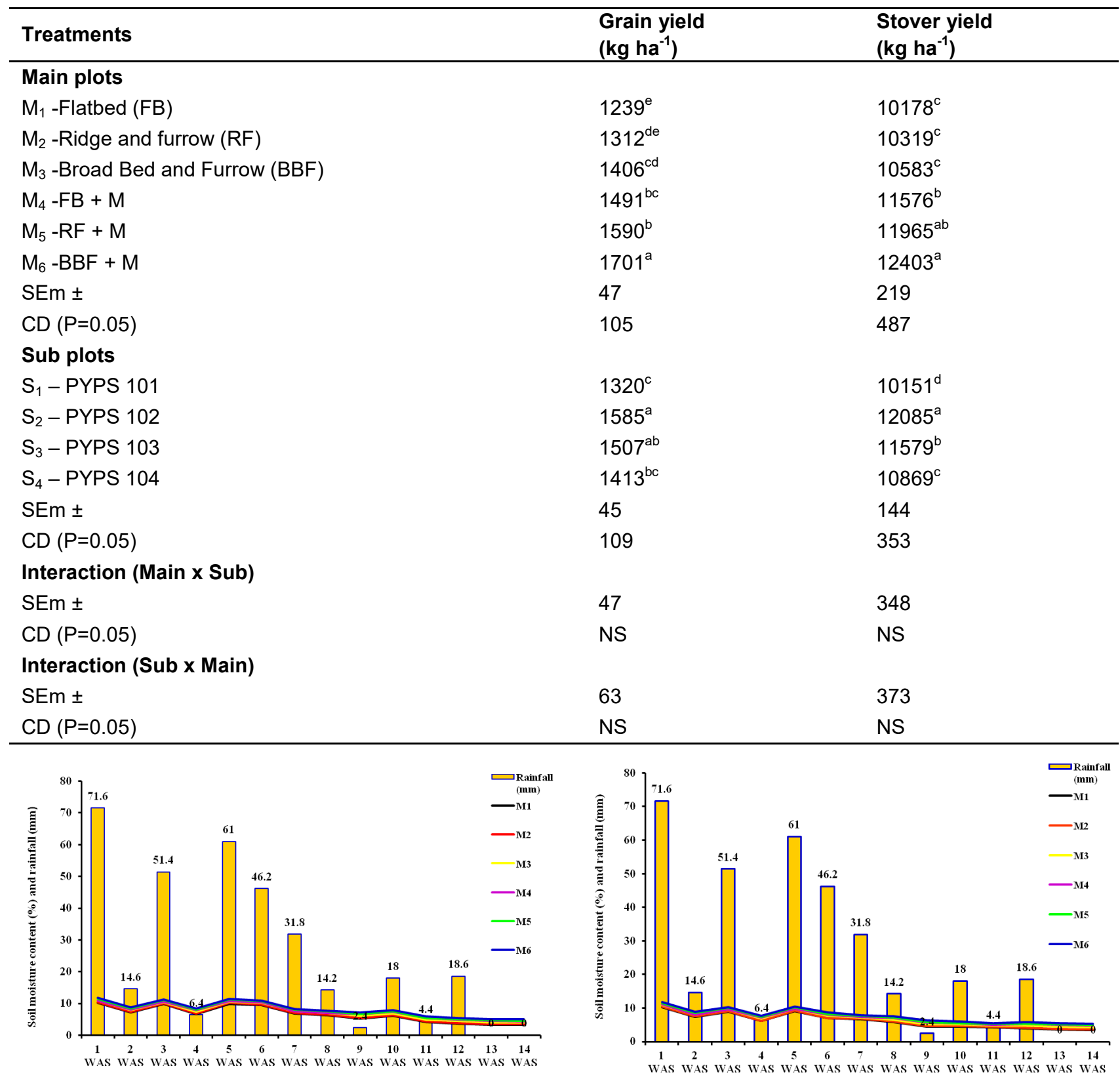

Fig. 1a. Soil moisture content (\%) at $0-15 \mathrm{~cm}$ soil depth under different land configurations in relation to rainfall.

ing this period, broad bed and furrows with mulch (M6) alone were found superior in maintaining a higher soil moisture regime in $0-15 \mathrm{~cm}$ soil depth. At any sampling week, irrespective of the rain events, the soil moisture contents in the surface layer $(0-15 \mathrm{~cm}$ soil depth) were maintained low (Fig. 2a) in flatbeds without mulch (M1) and ridges and furrows without mulch (M2).

A similar trend of soil moisture contents was noticed in $15-30 \mathrm{~cm}$ soil depth (Fig 1b \& 2b. During the weeks when there are rain events, the soil moisture contents were low in the subsurface layer $(15-30 \mathrm{~cm})$ as compared to the surface $(0-15 \mathrm{~cm})$ layer. Also, moisture

Fig. 1b. Soil moisture content (\%) at $15-30 \mathrm{~cm}$ soil depth under different land configurations in relation to rainfall.

contents were higher under broad beds and furrows with mulch $\left(M_{6}\right)$ and ridges and furrows with mulch $\left(M_{5}\right)$. However, the subsurface layer $(15-30 \mathrm{~cm}$ soil depth) maintained slightly higher moisture contents than the surface layer $(0-15 \mathrm{~cm})$ during the weeks where there was no rain. However, genotypes remained indifferent concerning soil moisture content.

Observation of soil moisture content at critical growth stages (Fig. 3a \& 3b) indicated that the moisture contents at booting (55 - 57 DAS) and flowering (66-68 DAS) stages were relatively higher (6.1 to $7.95 \%)$ as compared to milky (76-86 DAS) and hard dough (87-95 


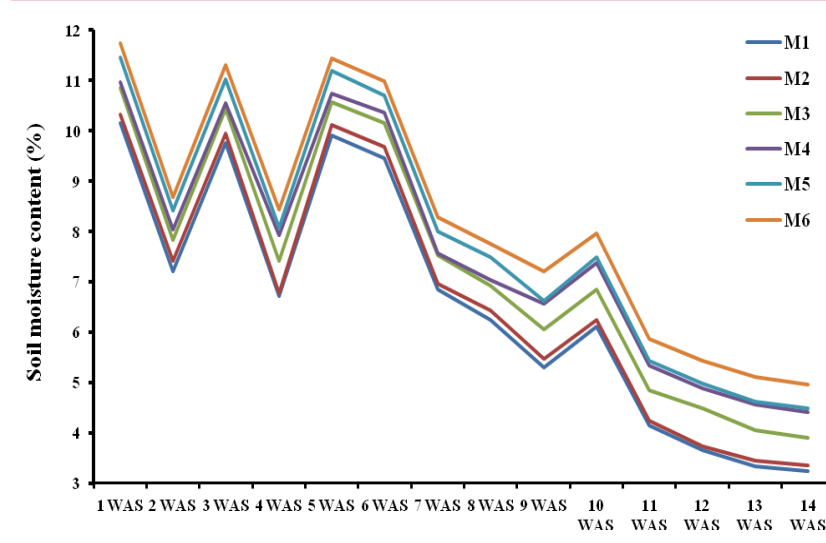

Fig. 2a. Soil moisture content (\%) at 0-15 cm depth under different land configurations.

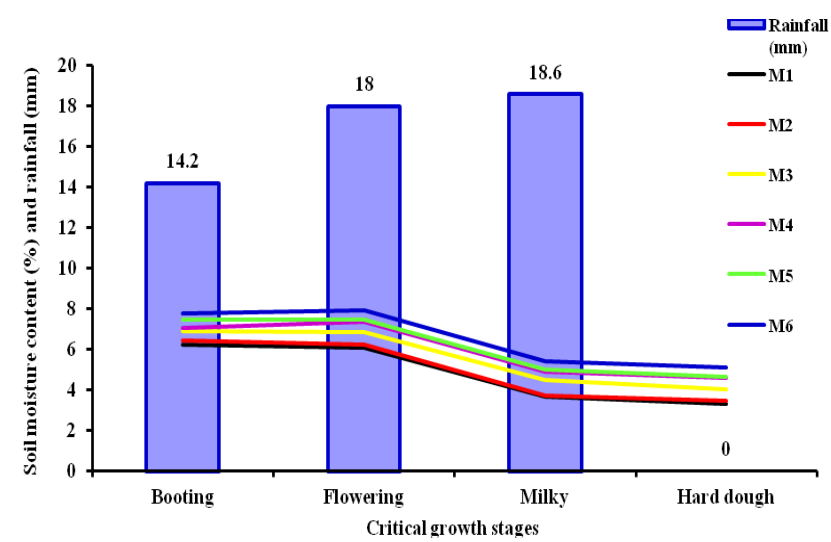

Fig. 3a. Soil moisture content (\%) in $0-15 \mathrm{~cm}$ soil depth at critical growth stages of yellow sorghum under different land configurations.

DAS) stages. Moreover, the crop received marginal rainfall of 1.5 to $2 \mathrm{~cm}$ in single rain events at critical stages viz., booting, flowering and milky stages, which sustained the crop even at lower soil moisture contents.

\section{Grain yield}

The grain yield of yellow pericarp sorghum manifested noteworthy variations among land configurations and genotypes (Table 1). However, land configurations and genotypes interacted together indifferently for grain yield.

Higher plant height, leaf area, dry matter production and yield attributes have contributed to the highest yield (1700 kg ha ${ }^{-1}$ ) under broad beds and furrows with mulch. Halli and Angadi (2018) reported that the optimum soil moisture might promote crop to express its full potential by utilizing soil moisture and the aerial environment. Srivatsava and Jangawad (1998) also reported higher yields with a broad bed and furrow method of planting in soybean, which might have helped in in-situ moisture conservation and improved root growth and nutrient access crop, thus increasing yield attributes and yield. Further, the leaf mulch has benefited from an increased infiltration rate, improved

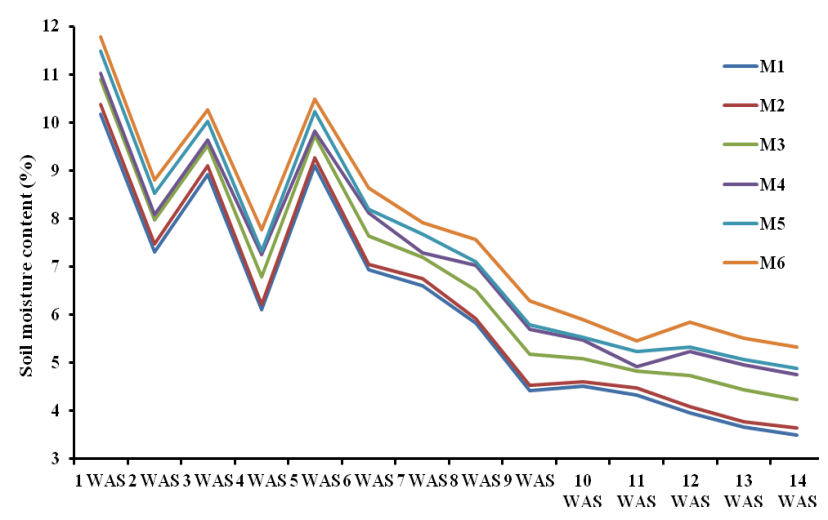

Fig. 2b. Soil moisture content (\%) at $15-30 \mathrm{~cm}$ depth under different land configurations.

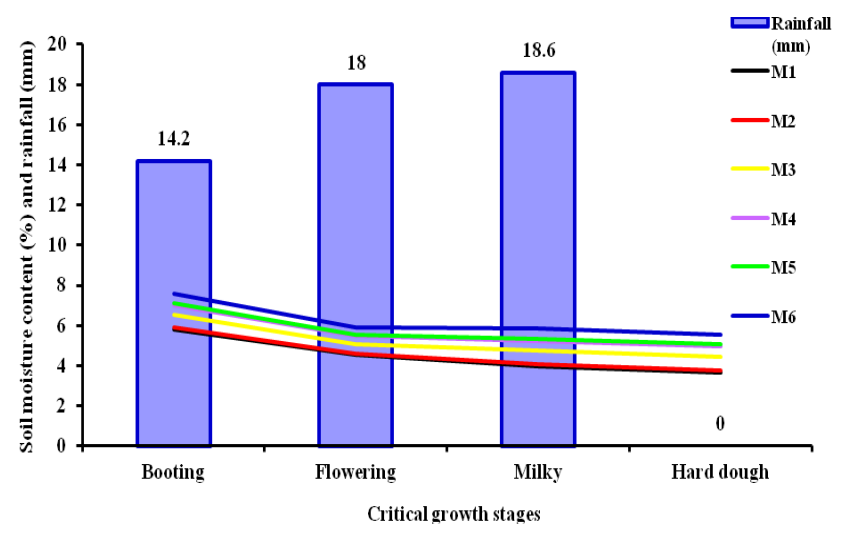

Fig. 3b. Soil moisture content (\%) in $15-30 \mathrm{~cm}$ soil depth at critical growth stages of yellow sorghum under different land configurations.

fertilizer availability, and increased crop yield (Dushouyu et al., 1995). Distinctively lowest grain yield of $1239 \mathrm{~kg} \mathrm{ha}^{-1}$ was observed under flatbed with no mulch $\left(M_{1}\right)$. Ridges and furrows with no mulch $\left(M_{2}\right)$ also were found comparable to $M_{1}$ with an equivalently lower yield of $1312 \mathrm{~kg} \mathrm{ha}^{-1}$. PYPS 102 (1585 kg ha-1) and PYPS 103 (1508 kg ha-1) faired equivalently well to register higher grain yield among the genotypes. PYPS 104 and PYPS 101 together were least with correspondingly lower grain yields (PYPS $104-1413 \mathrm{~kg} \mathrm{ha}^{-1}$ and PYPS 102 - $1320 \mathrm{~kg} \mathrm{ha}^{-1}$ ).

\section{Stover yield}

A perusal of the data indicated that stover yields were comparable and higher (12403 and $11965 \mathrm{~kg} \mathrm{ha}^{-1}$, respectively) under broad beds and furrows with mulch $\left(M_{6}\right)$ and ridges and furrows with mulch $\left(M_{5}\right)$. The counterpart treatments of $M_{4}, M_{5}$ and $M_{6}$, i.e., flatbed $\left(M_{1}\right)$ and ridges and furrows $\left(\mathrm{M}_{2}\right)$ and broad beds and furrows $\left(M_{6}\right)$ without mulch registered stover yields of 10178,10319 and $10583 \mathrm{~kg} \mathrm{ha}^{-1}$, respectively and were found least among the treatments. This attribute might improve moisture content in different soil depths (0-15 $\mathrm{cm}$ and $15-30 \mathrm{~cm}$ ) at different crop growth stages. 
These results were according to Jnanesha et al. (2016) and Halli and Angadi (2018). In the present study, PYPS 102, with the significantly highest stover yield of $12085 \mathrm{~kg} \mathrm{ha}^{-1}$ outperformed the other genotypes among the genotypes, whereas PYPS 101 was noted to be the least (10151 $\left.\mathrm{kg} \mathrm{ha}^{-1}\right)$ regarding stover yield.

\section{Conclusion}

The soil moisture contents varied according to the rainfall that occurred during the crop growth period. The soil moisture content of $0-15 \mathrm{~cm}$ soil depth was found equivalent both in ridges and furrows with mulch (M5) and broad beds and furrows (M6) with mulch whenever there is a rain event during any week. However, during the weeks when there is no rain, the soil moisture contents were highest under broad beds and furrows with mulch (M6). A similar trend of soil moisture contents was noticed in $15-30 \mathrm{~cm}$ soil depth. During the weeks when there were rain events, the soil moisture contents were low in the subsurface layer $(15-30 \mathrm{~cm})$ compared to the surface $(0-15 \mathrm{~cm})$ layer. Also, moisture contents were higher under broad beds and furrows with mulch (M6) and ridges and furrows with mulch (M5). However, the subsurface layer (15-30 cm soil depth) maintained slightly higher moisture contents than the surface layer $(0-15 \mathrm{~cm})$ during the weeks where there was no rain. However, genotypes remained indifferent to soil moisture content. The interaction of genotypes with land configurations also was found insignificant. Broad bed and furrow with Pongamia leaf mulch @ $6 \mathrm{t} \mathrm{ha}^{-1}$ were favourable to achieve higher grain and stover yields in yellow sorghum during kharif.

\section{Conflict of interest}

The authors declare that they have no conflict of interest.

\section{REFERENCES}

1. Agricultural Statistics at a glance (2016). Government of India, India

2. Ankita Negi., Aaradhana Chilwal \& Reshma Bora. (2018). Effect of soybean varieties under different land configurations on soil moisture stress. Int. J. Curr. Microbial. App. Sci., 7 (11), 2130-2134.

3. Dinesh Jinger., Sharma, R.K. \& Tomar, B.S. (2017). Moisture conservation practices for enhancing productivity in rainfed agriculture. Indian Farming. 67(06), 06-10.

4. Dushouyu, T., Enping, W. M. \& Wqingshan. (1995). A study of the overall effect of straw mulching and ploughing in and techniques for its applications. Ningxia J. Agri. Forest Sci. Technol., 5 (2), 10-14.

5. Gnanasoundari, P. \& Balusamy, M. (2015). Evaluation of land Configuration and mulching on soil moisture retention and yield of rainfed Cotton. Pop. Kheti, 3 (3), 326-331.

6. Halli, H.M. \& Angadi S.S. (2018). Influence of land configuration on rain water use efficiency, yield and economics of cowpea (Vigna unguiculata L.) in maize-cowpea sequence cropping under rainfed condition of northern transitional zone. Leg. Res., 34(6), 1701-1708.

7. Jnanesha, A. C., Alagundagi, S. C., Mansur, C. P. \& Ashish kumar. (2016). Effect of broad bed and furrow and integrated nutrient management practices on growth and yield of maize. The Ecoscan., Special issue, Vol. IX, 10171021.

8. Singh, R.J., Mandal, D., Ghosh, B.N., Lekh Chand, Alam, N.M. \& Sharma, N.K. (2015). Efficient Soil and Water Management under Limited Water Supply Condition. Ind. J. Agri. Sci., 78(1), 53-57.

9. Sarolia, D. K. \& Bhardwaj, R. L. (2012). Effect of mulching on crop production under rainfed condition: A review. Int. J. Res. Chem. Environ., 2, 8-20.

10. Srivatsava, K.K. \& Jangawad, L.S. (1998). Water balance and erosion rates of vertisols watersheds under different management. Indian J. Dryland Agril. Res. Dev., 3, 137144. 